\title{
Serious Human Rights Violations - Eclipse Or Mere Twilight of State Immunity?
}

\section{Ondřej Svaček ${ }^{\star}$}

\section{Faculty of Law, Palacký University Olomouc, Czech Republic email: ondrej.svacek@upol.cz}

SVAČEK, Ondřej. Serious Human Rights Violations - Eclipse or Mere Twilight of State Immunity? International and Comparative Law Review, 2011, Vol. 11., No. 2, pp. 63-78. DOI: 10.1515/iclr-2016-0104.

\begin{abstract}
Presented article contributes to the extensive discussion over the mutual relationship between serious human rights violations (violation of ius cogens) and the law of state immunity. The structure of article derives from the argumentation presented by Germany and Italy in current dispute before the International Court of Justice. Author focuses his attention on delimitation of existing international legal framework and particularly on assessment of friction areas in German and Italian submissions. Three separate issues are analyzed: temporal, territorial and material.
\end{abstract}

Keywords: State immunity, human rights violations, ius cogens

\section{Introduction}

At the end of 2008 Germany initiated proceedings against Italy before the International Court of Justice (hereafter ICJ) alleging that "Italian judicial bodies have repeatedly disregarded the jurisdictional immunity of Germany as a sovereign State." The matter of the dispute rests in the judgment in Ferrini case of the Italian Corte di Cassazione rendered on 11 March 2004. Italian Supreme Court was seized by civil claim brought against Germany by plaintiff who was deported in 1944 by German troops from Italy to German Reich where he was forced to work for war industry. Ferrini petitioned Germany for physical and psychological harm due to the inhuman treatment he was subjected to during his imprisonment. ${ }^{2}$ While lower instances dismissed the case arguing by lack of

\footnotetext{
* Department of Constitutional Law and Public International Law, Faculty of Law, Palacký Univerzity, Olomouc, Czech Republic.

1 Application Instituting Proceedings. Jurisdictional Immunities of the State (Germany v. Italy: Greece intervening) [online]. International Court of Justice, 23 December 2008 [cit. 3 December 2011]. Available from <http://www.icj-cij.org/docket/files/143/14923.pdf >.

2 DE SENA, Pasquale - DE VITTOR, Francesca. State Immunity and Human Rights: The

\section{(c) Palacký University Olomouc, Czech Republic, 2011. ISSN 1213-8770 (print), ISSN: 2464-6601 (online).}


jurisdiction, Italian Supreme Court completely overturned these opinions and ruled in favor of appellant. Ferrini decision opened notional Pandora's box and stimulated already hot discussion over the mutual relationship between serious violations of human rights and the law of state immunity. Obvious question, which is in the centre of presented article, is whether the law of state immunity is perforated by a newly established exception, i.e. by serious violation of human rights which form part of ius cogens? This issue has always been popular among scholars, but thanks to ongoing proceedings before the ICJ it currently gains the highest possible recency.

Presented article is divided into three parts. In the brief first part, the emphasis is put on the notion of state immunity as such, with particular focus on the evolution of state immunity, which is significantly marked with its continuous limitation. Second part describes current legal framework (treaties, relevant case-law) in specific area of state immunity which is of primary importance for this article, namely in the area of state immunity for serious violations of human rights. Third part analyzes potential arguments in favor of change of existing law, it explores whether in cases of human rights violation it is already valid to make state immunity inapplicable. Primary source of reference is the argumentation presented by German and Italian governments in the Jurisdictional Immunities of the State Case (hereafter Immunity Case), both in its written and oral part. The third part also tries to predict final judgment of the ICJ which, if rendered, would be of the highest importance for international law in this area as it is for the very first time when the ICJ is engaged in such kind of dispute.

\section{The Notion of State Immunity and Its Historical Evolution}

State immunity protects a state and its property from the jurisdiction of the courts of another state. State immunity "is a plea relating to the adjudicative and enforcement jurisdiction of national courts which bars the municipal court of one State from adjudicating the disputes of another State." ${ }^{3}$ It is product and direct consequence of unique character of public international law which provides for sovereign equality of states: par in parem non habet imperium. ${ }^{4}$ State immunity evolved in connection with the development of the concept of sovereignty and the territorial state, it is fundamental principle of the international legal order. State immunity is still based on customary international law as its codification effected by the United Nations Convention on Jurisdictional Immunities of States and Their Property (hereafter UN Convention) adopted in 2004 has not yet entered into force. ${ }^{5}$

Italian Supreme Court Decision on the Ferrini Case. EJIL. 2005, vol. 16, no. 1, p. 93.

3 FOX, Hazel. The Law of State Immunity. $2^{\text {nd }}$ edition. Oxford : Oxford University Press, 2008, p. 1.

4 Report of the Working Group on jurisdictional immunities of States and their property, YILC (1978), vol. II, Part Two, p. 153.

5 Convention shall enter into force on the thirtieth day following the date of deposit of the 
The doctrine of state immunity has evolved significantly over the last centuries. Originally, immunities enjoyed by states were of absolute character. State could invoke them even in entirely private legal relations. When states became increasingly engaged in commercial activities, it was felt there was a need to secure their accountability in business transactions and thus to limit their immunity only to activities which were done in public capacity. ${ }^{6}$ During $19^{\text {th }}$ and $20^{\text {th }}$ century some domestic courts therefore applied restrictive doctrine of state immunity which distinguishes as between acta iure imperii and acta iure gestionis. Very first case to be usually given as example of this historical shift dates from as early as 1840 , when the Attorney-General of the Court of Appeals of Brussels argued in favor of the denial of foreign state immunity with regard to private acts. ${ }^{7}$ Under the restrictive state immunity doctrine there are proceedings in which immunity cannot be invoked. ${ }^{8}$ The UN Convention enumerates following exceptions: commercial transactions (Art 10), contracts of employment (Art 11), personal injury and damage to tangible property (Art 12), ${ }^{9}$ ownership, possession and use of property (Art 13), intellectual and industrial property (Art 14), participation in companies or other collective bodies (Art 15), ships owned or operated by states which are used for commercial purposes (Art 16).

There is quite broad agreement among states that exceptions in the UN Convention reflect international custom and are "in line with current state practice."10 Practically identical opinion has been adopted by the Czech courts. In 2008 the Czech Supreme Court considered labor dispute between Poland and petitioner, who was employed as driver at Polish embassy in Prague, and ruled in favor of claimant despite Poland pointed out to its sovereign immunity and objected that the Czech courts lack jurisdiction. In its reasoning the Supreme Court held that if "State acts not as sovereign but as a legal person in disputes arising out from legal

thirtieth instrument of ratification. As on the date of writing (December 2011) there were only 13 state parties to this convention. The Czech Republic is signatory from 2006, but has not yet ratified the treaty. Despite very low support which has been shown until nowadays, the UN Convention is "the most authoritative statement available on the current international understanding of the limits of state immunity in civil cases." BROWNLIE, Ian. Principles of International Law. $7^{\text {th }}$ edition. Oxford : OUP, 2008, p. 347.

6 STOLL, Peter-Tobias. State Immunity. [online]. Max Planck Encyclopedia of Public International Law, August 2011 [cit. 12 December 2011], $\$ 6$. Available from <http://www. mpepil.com/subscriber_article?script=yes\&id=/ epil/entries/law-9780199231690-e1106\& recno $=1 \&$ searchType $=$ Quick\&query $=$ State + Immunity $>$.

7 Immunity Case, Counter-Memorial, $\$ 4.15$. The proper criterion for the distinction between acta iure imperii and acta iure gestionis is the nature of the act, not its purpose. Compare FOX, Hazel. International Law and Restraints on the Exercise of Jurisdiction By National Courts of States. In International Law. EVANS, Malcolm. 1st edition. Oxford : Oxford University Press, 2003, p. 361.

8 YILC (1991), vol. II, Part Two, p. 33, §3. Compare Part III of the UN Convention (Arts 10-17).

9 Compare Section 3b).

10 Fox, H.: supra note 3, p. 532. 
relations defined by equality between their parties, this legal person - foreign State -according to the norms of public international law does not enjoy immunity from national proceedings." 11 The court referred to the Report of the Working Group on Jurisdictional Immunities of States and highlighted exactly the same exceptions to state immunity as these mentioned in the UN Convention. Following parts shall consider whether the same argument can be presented with respect to serious violations of human rights.

\section{State Immunity for Serious Human Rights Violation - Legal Framework}

After short introduction of subject-matter, it is necessary to specify legal framework (treaties, international case-law, relevant domestic case-law used as evidence of state practice) in specific area of state immunity, i.e. in the area of state immunity for serious human rights violations.

Currently, there is no international treaty which would address this particular issue, callings for conventional regulation remain to be limited on doctrinal sphere. ${ }^{12}$ There are no hard exceptions regarding non-immunity for serious human rights violations, but certain indicias worth to be mentioned. ${ }^{13}$ Of importance are Art 11 of the European Convention on State Immunity (hereafter European Convention) and similar provision of Art 12 of the UN Convention. These articles provide for so-called tort exception to state immunity, which is nevertheless limited to the territory of the forum state. If tort (wrongful act) is committed abroad, i.e. not on the territory of the state whose courts are seized in the matter, these provisions are inapplicable. Unfortunately, such scenario would be rather rule than exception. As far as potential existence of a customary rule is concerned, it shall be further discussed in the following section.

Due to the lack of primary sources, one must take into account existing judicial practice as subsidiary mean for the determination of rules of law. The European Court of Human Rights (hereafter ECHR) dealt with the matter in at least four decisions which are therefore seminal for every discussion over the topic. In 2001 (at the same day though in separated proceedings) judgments in $\mathrm{Al}$ Adsani, ${ }^{14}$ McElhinney ${ }^{15}$ and Fogarty ${ }^{16}$ were rendered. First case concerns a British and Kuwaiti national who had allegedly been tortured while in Kuwait. After his

11 Supreme Court Decision, 25th June 2008, 21 Cdo 2215/2007.

12 HALL, Christopher Keith. UN Convention on State Immunity: the Need for a Human Rights Protocol. ICLQ. 2006, vol. 55, no. 2, p. 411-26.

13 BRÖHMER, Jürgen. State Immunity and the Violation of Human Rights. The Hague : Kluwer Law International, 1997, p. 135.

14 Al-Adsani v. the United Kingdom. Appl. no. 35763/97, ECHR Grand Chamber Judgment, 21 November 2001 (hereafter Al-Adsani).

15 McElhinney v. Ireland. Appl. no. 31253/96, ECHR Grand Chamber Judgment, 21 November 2001 (hereafter McElhinney).

16 Fogarty v. the United Kingdom, Appl. no. 37112/97, ECHR Grand Chamber Judgment, 21 November 2001. 
return to the UK he initiated proceedings against Kuwait claiming damages for suffered injury. Second case deals with incident from March 1991 which came about at the Northern Ireland border - a British soldier was carried over the border on the tow-bar of the McElhinney's vehicle. After all, the applicant was allegedly assaulted by the soldier in Ireland. Last of the trinity touches rather labor dispute. In 2002 the ECHR decided about inadmissibility of claim presented by 257 victims of WW 2 massacre committed by German soldiers in Greece. ${ }^{17}$ This case refers to infamous killing of Distomo villagers in 1944. In all cases considered by the ECHR, violation of Art 6 (right to fair trial) was claimed, but all applications were finally unsuccessful, as the ECHR denied withdrawal of immunities of respondent states. Currently, there are few other cases still pending before the ECHR. Factual background of these cases is similar to Al-Adsani. In Jones $v$. the United Kingdom (conjoined with Mitchell and others $v$. the United Kingdom) applicant, British national, was falsely accused of involvement in a bombing campaign which occurred in Saudi Arabia in 2001. He had been taken away by secret police directly from hospital and then tortured and mistreated for no less than 67 days. In Naït-Liman v. Switzerland Tunisian national, while living in Italy, was arrested and abducted to Tunis. Over a period of 40 days he was arbitrarily detained and subjected to torture. He later fled to Switzerland where he was granted refugee status. National courts in both cases refused to award claimed damages with argument they did not have jurisdiction as alleged acts were committed abroad and they must have respected state immunity of Saudi Arabia and Tunisia. ${ }^{18}$

Relevant practice of domestic courts is far more extensive and cannot be enumerated at full length. Germany puts forward cases from Poland, Serbia, Belgium, Slovenia, France (Bucheron v. Germany), the United Kingdom (Jones v. Saudi Arabia), the United States (Princz v. Germany), Canada (Bouzari v. Iran) and Greece, understandably all supportive of its own position. Especially Greek case-law is of the utmost importance for Immunity Case. In Voiotia v. Germany Greek Supreme Court for the first time addressed massacre in Distomo village. With reliance on the tort exception, as described above, it applied restrictive doctrine of state immunity and decided in favor of petitioners. No enforcement of this judgment was nevertheless reached in Greece, due to Minister of Justice's refusal to authorize it (Art 923 of the Greek Civil Procedure Code), ${ }^{19}$ moreover this decision was overruled in 2002 by Special Supreme Court in Margellos v. Germany. ${ }^{20}$ After Ferrini decision was released in Italy, Greek petitioners moved

17 Kalogeropoulou et al. v. Greece and Germany. Appl. no. 59021/00, ECHR Decision on Admissibility, 12 December 2002.

18 Jones v. Ministry of Interior Al-Mamlaka Al-Arabyia AS Saudiya (the Kingdom of Saudi Arabia), House of Lords Judgment, 14 June 2006 (hereafter Jones v. Saudi Arabia).

19 Thereupon claimant introduced application against Greece and Germany before the ECHR - compare supra note 17.

20 Special Supreme Court was convened according to Art 100 of the Greek Constitution with the aim (and constitutional power) to settle controversies related to the designation of 
with its claims to Italy and finally succeeded, as Court of Appeal of Florence found Distomo judgment enforceable in Italy. Due to the considerable cohesion between Ferrini and Distomo cases, the ICJ granted Greece permission to intervene in the Immunity Case as a non-party in 2011 order. Last, but not least, state practice can be revealed not only in judicial practice, but surely in practice of legislature. This would concern above all statutes enacted in common law countries (e.g. the UK State Immunity Act, the US Foreign Sovereign Immunities Act, the Canadian State Immunity Act) - these documents are nevertheless silent about human rights.

\section{Friction Areas in Parties' Submissions - What Solution for German-Italian Dispute?}

In the last and central part of presented paper the focus is given on particular friction areas in German and Italian submissions presented both in written and oral part of the proceedings in Immunity Case before the ICJ. By friction areas fundamental disagreement over specific legal issues is meant. Among these issues attention shall be given to following questions: (a) whether state immunities are of substantive or procedural character; (b) whether locus delicti commissi has relevance for granting or withholding of immunities; (c) whether ius cogens norms can prevail over dispositive rules of state immunity? The first question reflects temporal application of state immunity, the second deals with territorial application. Last issue refers to hierarchy of norms in current public international law.

\section{a) Character of State Immunity and Aspect of Inter-Temporal Law}

German and Italian submissions differ significantly from the very starting point. Germany describes state immunities as substantive rules which derive from the sovereign equality of states (Art 2 (1) of the UN Charter) and which have "little, if anything to do with procedure. "21 Contrary to German arguments, Italy describes immunity as a procedural rule which affects the jurisdictional competence of a court, i.e. which acts as a procedural bar once judicial proceedings is initiated. ${ }^{22}$ Proper classification of state immunity nature is not only of academic relevance, as it has significant impact on applicable law. If state immunity is defined as substantive rule, it is widely accepted that it must be assessed according to the law in force at the time when relevant juridical facts occurred - in framework of Immunity Case this should be law in force between 1943 and 1945. On the other hand, if state immunity is defined as procedural rule, it should be assessed on the basis of the law in force at the time when the court is

rules of international law. Margellos v. Germany. Special Supreme Court (Anotato Eidiko Dikastirio) Judgment, 17 September 2002, \$\$ 14-15 (hereafter Margellos v. Germany).

21 Immunity Case, Memorial, p. 57, $\$ 92$.

22 Immunity Case, Counter-Memorial, p. 11, § 1.17. 
seized. The latter variant opens door for evaluation of development which public international law has undergone from the end of WW 2 till 2008, when current dispute was initiated. ${ }^{23}$

Character of state immunity has been described in procedural terms in caselaw of international and national tribunals. It determines the forum before which the case is held and, at the same time, does not affect underlying substantive right or duty of petitioner or defendant. ${ }^{24}$ In Al-Adsani the ECHR ruled that " $\left.\mathrm{t}\right] \mathrm{he}$ grant of immunity is to be seen not as qualifying a substantive right but as a procedural bar on the national courts' power to determine the right. ${ }^{\text {"25 }}$ The same wording was adopted in McElhinney and Fogarty rendered by the ECHR on the same day. In 2006 House of Lords issued its judgment in Jones v. Saudi Arabia where Lord Bingham with reference to The Law of State Immunity, leading treatise in area written by Hazel Fox, observed:

State immunity is a procedural rule going to the jurisdiction of a national court. It does not go to substantive law; it does not contradict a prohibition contained in a jus cogens norm but merely diverts any breach of it to a different method of settlement. Arguably, then, there is no substantive content in the procedural plea of State immunity upon which a jus cogens mandate can bite. ${ }^{26}$

Procedural character of immunities was stressed even by the ICJ in Democratic Republic of Congo v. Belgium, though subject matter of this dispute dealt with immunities of state organs granted for purpose of criminal proceedings. The ICJ held that " $[\mathrm{w}]$ hile jurisdictional immunity is procedural in nature, criminal responsibility is a question of substantive law. ${ }^{\text {"27 }}$ In the ICJ advisory opinion over Difference Relating to Immunity from Legal Process of a Special Rapporteur of the Commission on Human Rights, one can find similar conclusion. ${ }^{28}$ It seems that prevailing opinion describes state immunity as procedural rule. Having made this conclusion, there is still one question left: what law to apply for state immunity? This brings us to the doctrine of inter-temporal law.

The doctrine of inter-temporal law was famously analyzed in Island of Las Palmas by Max Huber who pointed out that " $a$ juridical fact must be appreciated in the light of the law contemporary with it, and not of the law in force at the time

23 Ibid, p. 60.

24 Mc GREGOR, Lorna. Torture and State Immunity: Deflecting Impunity, Distorting Sovereignty. EJIL. 2008, vol. 18, no. 5, p. 907.

25 Al-Adsani, $\$ 48$.

26 Jones v. Saudi Arabia, \$24. Compare FOX, H.: supra note 3, p. 151.

27 Case Concerning the Arrest Warrant of 11 April 2000 (Democratic Republic of Congo v. Belgium), Judgment, 14 Feb. 2002, p. 25, $\$ 60$ (hereafter Arrest Warrant Case).

28 Difference Relating to Immunity from Legal Process of a Special Rapporteur of the Commission on Human Rights, Advisory Opinion, 29 April 2009, p. 88, $\$ 63$. 
when a dispute in regard to it arises or falls to be settled. "29 This principle acts as guarantor of stability and legal certainty of law and as such is of the utmost importance in any legal system. Huber's statement has been widely accepted to this very day despite its frequent misinterpretation, especially with connection to the second element of his dictum. ${ }^{30}$ Generally speaking, judicial facts must be assessed according to the law in force at the time when the facts occurred. There is no law without exceptions however, and it holds true for inter-temporal rule as well. First exception is adherent to human rights treaties which are to be interpreted in the light of present-day conditions. Most known examples of this progressive interpretation emanate from the practice of the ECHR. ${ }^{31}$ In cases dealing with state immunity and serious violation of human rights, the ECHR has not yet accepted that Art 6, guaranteeing right to fair trial, of the Convention on Human Rights and Fundamental Freedoms, which is always invoked by petitioners, should be interpreted in such a manner, as to allow penetration of state immunity. Quite contrary, with reference to margin of appreciation doctrine, the ECHR stresses the lack of state practice in area, or more precisely, its heterogeneity - it is therefore up to states to make up relevant and constant precedents which could be approved subsequently by international judicial bodies. ${ }^{32}$ Arguably this creates egregious vicious circle.

Second exception points to the area of procedural rules. There is stable practice that any courts (both national and international) should apply procedural rules which are in force at the time when the courts are seized. If state immunity is considered as procedural rule, one can make conclusion that inter-temporal principle is not applied. ${ }^{33}$ As far as dispute between Germany and Italy is concerned, relevant time framework would be year 1998, when Corte di Cassazione declared that Italy held jurisdiction with regard to claim in Ferrini case, and year 2008 when dispute was presented before the ICJ. Such outcome is to the certain extent undesirable (as there is ten years gap which can be of some importance, i.e. the ICJ should take into account potential development of law within these

29 Immunity Case, Memorial, p. 57, $\$ 93$.

30 Ibid, p. 59, $\$ 94$. The second element provides that "the existence of the right, in other words its continued manifestations, shall follow the conditions required by the evolution of the law" and arguably opens doors for evolution or change within applicable legal rules. Such consequences were however never intended - compare HIGGINS, Rosalyn. Some Observations on the Inter-Temporal Rule in International Law. In Theory of International Law at the Threshold of the $21^{\text {st }}$ Century. Essays in Honour of Krzysztof Skubiszewski. The Hague : Kluwer Law International, 1996, p. 174.

31 Selmouni v. France. Appl. no. 25803/94, ECHR Grand Chamber Judgment, 28 July 1999, $\S 101$.

32 McElhinney, $₫ 38, \S 40$, Al-Adsani, $₫ 53$.

33 OELLERS-FRAHM, Karin. Judicial Redress of War-related Claims by Individuals: the Example of the Italian Courts. In From Bilateralism to Community Interest: Essays in Honour of Bruno Simma. Oxford: OUP, 2011, p. 1072. Oellers-Frahm nevertheless argues in favor of state immunity defined as substantive rule, which leads to full application of inter-temporal law principle. 
ten years), but if state immunity is considered thoroughly as the institute of procedural law, it is at the same time the only possible solution and interpretation. Immunity Case before the ICJ is moreover somehow specific, as it refers to the events which occurred during WW 2 - the problem of inter-temporal law would not be topical if wrongful act is committed in recent years. Anyway, it must be assessed whether current international law allows for newly created exception in the law of state immunity, namely penetration of state immunity in situation of serious violations of human rights. Before this crucial issue is answered relevance of loci delicti commissi shall be considered.

\section{b) Territorial Aspect in the Law of State Immunity}

Question which is to be addressed in the following section is whether the venue, where wrongful acts take place, has influence on granting or withholding of state immunities. To give example, one may ask whether legal assessment would be different if offence is done abroad or on the territory of a forum state. ${ }^{34}$ This issue is important even in the Immunity Case, as the wrongful act committed by Germany took place at least partly in Italy. ${ }^{35}$ The most important rule dealing with territorial aspects of state immunity is Art 12 of the UN Convention. Although this convention is not yet in force, it is the most relevant source of the law of state immunity and therefore has to be taken into account.

This article (i.e. Art 12 of the UN Convention) is listed among exceptions to state immunity. It says that state A cannot invoke immunity from jurisdiction before a court of state B which is otherwise competent in a proceeding which relates to pecuniary compensation for death or injury to the person, or damage to or loss of tangible property, caused by an act or omission which is alleged to be attributable to the state $\mathrm{A}$, if the act or omission occurred in whole or in part in the territory of state B and if the author of the act or omission was present in that territory at the time of the act or omission. This rule is rather complex, but at the first sight it is clear that immunity can only be invoked in situations where wrongful act was committed on the territory of the forum state. The rationale behind this rule is simple - the most convenient court is that of the state where the delict was committed. There is no similar rule which would make state immunity inapplicable when such conduct occurred outside the territory of the forum state. According to Fox, "[t]he possibility of removing immunity [in such situations] [...] was never discussed by the ILC and would certainly have been treated as out of order. ${ }^{\text {“36 }}$ Territorial aspect was crucial even in Al-Adsani where majority of the ECHR ruled out that it did not "find established that there is yet acceptance in international law of the proposition that States are not entitled to immunity in respect of civil claims for damages for alleged torture committed outside the forum

34 By forum state a state, where proceedings against another state is initiated, is meant.

35 Immunity Case, Counter-Memorial, p. 15, \$2.8.

36 Fox, H.: supra note 3, p. 587. 
State. ${ }^{\left({ }^{37} 7\right.}$ There is at least accepted, even though supporters of human rights would like to push the rule much further, that death or injury to the person which result from incidents committed in the forum state are not covered by the law of state immunity. It is worth to dwell on the matter for a while.

The original scheme of Art 12 was narrower. It should have been tailored and "mainly concerned with accidental death or physical injuries to persons or damage to tangible property involved in traffic accidents, such as moving vehicles, motor cycles, locomotives or speedboats. ${ }^{\text {" } 38}$ All proposals to limit Art 12 only to traffic accidents were fortunately rejected. In one breath the International Law Commission (hereafter ILC) commentary adds that the "scope of article 12 is wide enough to cover also intentional physical harm such as assault and battery, malicious damage to property, arson or even homicide, including political assassination. ${ }^{\prime \prime 9}$ The rule has dispositive character, it is used unless otherwise agreed between the states concerned, plus, the existence of two cumulative conditions has to be fulfilled for application of this exception. First, the act must be committed at least partly in the territory of the forum state and second, the author of such act or omission must also be present in that state at the time of the act or omission. Such solution was criticized, because it excludes some transboundary damages (firing or shooting across the border), e.g. those resulting from an armed conflict. ${ }^{40}$ Next, there is no need to distinguish between acta iure imperii and acta iure gestionis, as the exception covers all types of acts irrespective of their character. Finally, as one commentator stressed, Art 12 of the UN Convention "is helpful only in a very small number of cases $^{\text {"41 }}$ - more typical would be Al-Adsani like scenario where petitioner suffers damage abroad and is unable to obtain redress directly in the forum state.

The most difficult issue connected with interpretation of Art 12 of the UN Convention is whether it covers claims arising from the armed conflict. ${ }^{42}$ It was argued that claims for damages resulting from transboundary effects of armed conflicts would be rejected without else, the answer is not so much clear with regard to armed conflicts occurring directly in the territory of the forum state. The UN Convention, contrary to its European regional counterpart, contains no express rule excluding its applicability to armed forces. The European Convention provides for such rule in Art 31 according to which "nothing in the present Convention shall affect any immunities or privileges enjoyed by a Contracting State in respect of anything done or omitted to be done by, or in relation to, its armed forces when on the territory of another Contracting State." It is of no wonder that Ger-

37 Al-Adsani, $\$ 66$.

38 YILC (1991), vol. II, Part Two, p. 45, § 4.

39 Ibid

40 Ibid, p. $45, \S 7$.

41 STOLL, P.-T.: supra note $6, \S 80$.

42 Immunity Case, Memorial, p. 43-51, $\$ \$ 71-82$, Immunity Case, Counter-Memorial, pp. $54-56, \S \S 4.37-4.42$. 
many argues against inclusion of armed forces to tort exception contained in Art 12, whilst Italy reasons just in favor of it. According to Germany this article was not tailored for situations of macro-injustices. ${ }^{43}$

Such argumentation has for sure merits and rests on variety of sources. Reference should be made again to the ILC commentary to Draft Articles of Jurisdictional Immunities of States and Their Property (commentary to Art 12) which speaks about inapplicability of Art 12 to situations involving armed conflicts. ${ }^{44}$ The ECHR, while interpreting Art 12 of the UN Convention in McElhinney, came to similar conclusion saying that "the trend may primarily refer to "insurable" personal injury, that is incidents arising out of ordinary road traffic accidents, rather than matters relating to the core area of State sovereignty such as the acts of a soldier on foreign territory" ${ }^{45}$ The same is true for Margellos case heard before Greek Special Supreme Court, which departed from previous Distomo case. Greek court came to conclusion that at the present stage of development of international law, a generally accepted rule of international law that allows an action to be brought against one state before the courts of another state for compensation arising from any type of tort that took place in the territory of the forum, and in which the armed forces of the defendant state were involved in any way, either in peace or in time of war, has not yet emerged. ${ }^{46}$ Lastly, rules excluding armed activities from framework of domestic legislation (e.g. State Immunity Act of the UK) can be traced in most common law countries.

Exhaustive investigation of the subject was conducted by A. Dickinson, who concludes that question of applicability of the UN Convention towards activities of armed forces is far from being answered. ${ }^{47}$ There are categories of privileges and immunities which are not affected by the convention (Art 3), the absence of any specific mention about immunities of armed forces tends (a contrario) to the conclusion that the UN Convention is simply applicable to armed activities. General regulation can be nevertheless replaced by specific agreements (e.g. status of force agreements) whose existence and availability are anticipated in Art 26 of the convention. Finally, Dickinson admits that " $[$ t]here may [...] be scope for bringing claims against individual members of foreign armed forces of States party to the Convention who commit war crimes outside the forum state“" 48 This conclusion gives

43 Immunity Case, Memorial, p. 46, § 75.

44 YILC (1991), vol. II, Part Two, p. 46, \$ 10. The ILC commentary is referred to even by G. Hafner, chairman of the UN Ad Hoc Committee on Jurisdictional Immunities of States and Their Property established by General Assembly in 2000, in his final report from 2005. Compare A/C.6/59/SROV.13, §§ 36-37.

45 McElhinney, $\$ 38$.

46 Germany v. Margellos, $\$ \$ 14-15$.

47 DICKINSON, Andrew. Status of Forces under the UN Convention on State Immunity. ICLQ. 2006, vol. 55, no. 2, p. 436.

48 Ibid 
floor for final section which deals with mutual relationship between ius cogens and dispositive rules of state immunity.

\section{c) Hierarchy of Norms in International Law - Ius Cogens and State Immunity}

It was already mentioned that Italian submission is based on simple assumptions: serious violations of international humanitarian law committed by German troops in Italy during WW 2 can be described as violations of ius cogens (a), as state immunity has only dispositive character (b), there is no doubt that a contradiction between two binding legal norms ought to be resolved by giving precedence to the norm with the higher status. ${ }^{49}$ At the very outset it needs to be stressed that mutual relation between ius cogens and state immunity concerns a linkage between peremptory and dispositive rules. The law of state immunity has in no way obtained status of imperative norms therefore there is no conflict of peremptory norms at stake. ${ }^{50}$

The opinion of scholars in this question is, without any surprise, divided. There are opinions arguing in favor of primacy of ius cogens over rules of state immunity and opinions which argue against ${ }^{51}$ - tertium non datur. Proponents usually argue by hierarchy of norms, opponents point out to the lack of practice in area, or refer to different character of peremptory norms and rules of state immunity. According to the latter plea, there is no space for contact between ius cogens and state immunity, because first rules have substantive content whilst second only procedural one. Accordingly, "state immunity only concerns the enforcement, not the material content of the jus cogens rule. ${ }^{\text {"52 }}$ It seems that such opinion is of no use in Immunity Case, as Germany from the very beginning contends that state immunity is of material character and Italy adopts position according to which ius cogens have effects even in area of procedural law. It is worth to describe relevant arguments at some length.

According to Italy, there are at least three reasons which can be submitted to give support for its position. First one rests in analogy with development in international criminal law. Perpetrators of crimes under international law cannot further shield behind the cloak of their function. At the latest from 1945, there is constant rule in international law according to which the official position of defendants, whether heads of state or responsible officials in government departments, shall not be considered as freeing them from responsibility or mitigating punishment..$^{53}$ Neither personal nor functional immunities are relevant in pro-

49 Immunity Case, Memorial, p. 51, $\$ 83$.

50 For contrary opinion compare OELLERS-FRAHM, K.: supra note 33, p. 1072.

51 ORAKHELASHVILI, Alexander. State Immunity and Hierarchy of Norms: Why the House of Lords Got it Wrong? EJIL. 2008, vol. 18, no. 5, p. 964.

52 BARTSCH, Kerstin - ELBERLING, Björn. Jus Cogens vs. State Immunity, Round Two: The Decision of the European Court of Human Rights in the Kalogeropoulou et al. v. Greece and Germany Decision. German Law Journal. vol. 4, no. 5, p. 484.

53 Charter of the International Military Tribunal, Art 7. 
ceedings before international tribunals. As far as proceedings before domestic courts are concerned, only personal immunities are applicable, but once a person ceases to hold the office, he or she will no longer enjoy any such protection - functional immunities are not relevant for crimes under international law..$^{54}$ To put it differently, as Italy suggests, it is untenable to maintain that while ius cogens have procedural effects in criminal proceedings, it cannot cause similar consequences in civil proceedings where state responsibility is concerned. To use another analogy, this situation somehow brings back discussion over criminalization of violation of international humanitarian law in non-international armed conflicts. It took some time before the ICTY famously ruled out that "[w] hat is inhumane, and consequently proscribed, in international wars, cannot but be inhumane and inadmissible in civil strife. " ${ }^{55}$ Tadić decision marked important step toward overcoming of that time prevailing doctrine of divided humanity which distinguished between different kinds of conflicts.

Second argument speaks about tacit waiver of immunity in situations of serious violations of human rights. This theory asserts that violation of ius cogens cannot be considered as sovereign act, and therefore, "[w]hen a State act is no longer recognized as sovereign, the State is no longer entitled to invoke the defense of sovereign immunity." ${ }^{\text {"56 }}$ In the opinion of present author this line of reasoning however lacks persuasiveness. It seems that such reading of waiver goes too far behind what would be acceptable for states, as waiver deals with expression of will, which would be simply missing in described situations. It is acceptable that waiver can be implied (e.g. state voluntarily takes part in initiated proceedings), but anyway states must still express somehow its readiness or willingness to confer jurisdiction to a court of another state. Mere fact that subject matter of the dispute deals with violation of ius cogens does not automatically generates jurisdiction of any court. Such conclusion has its resonance even in case-law of the ICJ. ${ }^{57}$

The last argument deals with already mentioned hierarchy of norms in public international law. Unfortunately, the source Italy refers to in its submission is only the minority opinion in Al-Adsani. Although the judgment of the ECHR Grand Chamber was decided only by the tightest possible majority (9:8), it is

54 Arrest Warrant Case, $₫ 61$.

55 Prosecutor v. Tadić. Case no. IT-94-1, Appeal Chamber, Decision on the Defence Motion for Interlocutory Appeal on Jurisdiction, 2 October 1995, $\$ 119$.

56 Immunity Case, Counter-Memorial, p. 65, §4.69.

57 Armed Activities in the Territory of the Congo (Democratic Republic of the Congo v. Rwanda), Judgment, 3 February 2006, p. 32, $\$ 64$ - according to the ICJ, ,the fact that a dispute relates to compliance with a norm having such a character, which is assuredly the case with regard to the prohibition of genocide, cannot of itself provide a basis for the jurisdiction of the Court to entertain that dispute. Under the Court's Statute that jurisdiction is always based on the consent of the parties." 
still this majority which prevailed. Minority opinion refers again to procedural effects of ius cogens in civil proceedings against states:

The acceptance therefore of the jus cogens nature of the prohibition of torture entails that a State allegedly violating it cannot invoke hierarchically lower rules (in this case, those on State immunity) to avoid the consequences of the illegality of its actions. [...] Due to the interplay of the jus cogens rule on prohibition of torture and the rules on State immunity, the procedural bar of State immunity is automatically lifted, because those rules, as they conflict with a hierarchically higher rule, do not produce any legal effect. ${ }^{58}$

German argumentation, if inter-temporal aspect discussed above is omitted, is twofold. First one deals with lack of any relevant state practice. In fact, Italy builds its arguments mainly on the judicial practice of its own courts. Even the closest counterpart of Ferrini judgment, namely the Greek Distomo case, was finally overcome by later ruling by the Special Supreme Court. As far as the ECHR is concerned, all cases connected with mutual relationship between serious human rights violations and state immunity (Al-Adsani, McElhinney, Fogarty, Kalogeropoulous) were decided in favor of the latter. Finally, even Ferrini case, which lies in the center of whole dispute, uses very cautious language, since Corte di Cassazione merely ruled out "it could be presumed that a principle limiting the immunity of a State which has committed crimes against humanity was in the process of formation. " 59 The court speaks about the process of formation of custom, not about already created customary rule.

An exception to state immunity which would be applicable in situations of serious human rights violations is not part of any international instrument, in the opinion of present author it can enter floor of international normativity only through the formation of new customary rule. Potential pronouncement in a decision of the ICJ or any other international tribunal would be of only declaratory character, as courts cannot create law, they can only apply it. Formation of custom in international law is subject to widely shared conditions, among which uniformity, extensiveness and representativeness are usually mentioned. ${ }^{60}$ It seems that practice, as far as immunity for human rights violation is concerned, is uniform, extensive and representative only in so far, as immunity is retained and preserved for states. Only one inter-state dispute which had been decided in favor of non-immunity was subsequently presented to the ICJ. Italian cases should be therefore "treated as breaches of [existing] rule, not as indications of the recognition

58 Al-Adsani, Joint Dissenting Opinion of Judges Rozakis and Caflisch Joined by Judges Wildhaber, Costa, Cabral Barreto and Vajić, $\$ 3$.

59 Immunity Case, Memorial, p. 52, $\$ 84$.

60 Final Report of the Committee on Formation of Customary (General) International Law, ILA London Conference (2000), p. 20. 
of a new rule."61 Despite sympathy for Italian submission, especially in the part speaking about analogy to the development in international criminal law, one cannot disregard fact that ius cogens and state immunity are shaped by will of the states, element of consent retains its importance in this area. In current state of international law states are evidently not ready to accept idea that they should sacrifice their immunity on the altar of omnipresent emphasis on human rights. Fortunately, all relevant practice and case-law in area favoring immunity do not exclude development in customary international law in the future. ${ }^{62}$

Ad abuntandiam, one more argument supportive of German position should be mentioned in this section. Until recently, claims brought by individuals relating to damages suffered during armed conflicts were unsuccessful, as they were governed by the law of armed conflict which provides no right to claim compensation on the part of individual. ${ }^{63}$ Reference is usually made to Art 3 of the Hague Convention respecting the Laws and Customs of War on Land and Art 91 of the Additional Protocol I to the 1949 Geneva Conventions. These provisions provide that belligerent party which violates the provisions of the said instruments shall, if the case demands, be liable to pay compensation. It shall be responsible for all acts committed by persons forming part of its armed forces. The acceptance of Italian argumentation would mean that cited rules of international humanitarian law have self-executing character which is far from being settled. Such position should be first accepted across the state practice and only after promulgated by international forum. It is preferable that situations of macro-injustices are compensated in macro terms as well, i.e. by lump-sum agreements. It means at the same time that cases of isolated violation of human rights should be governed differently. In the light of previous analysis it is clear that such idea has not yet been accepted by states.

\section{Conclusion}

It is often said that every paper should be reformulable into simple questionanswer scheme. The question was revealed in the very title of present article: is state immunity already non-applicable (eclipse) in situations of serious human rights violations? The answer is simple: no! More complex answer would be: not yet (twilight). This position takes into account development of international law, its shift towards individual, but at the same time reflects the lack of relevant state practice in the area.

61 Case Concerning Military and Paramilitary Activities in and against Nicaragua (Nicaragua v. United States of America), Judgment, 27 June 1986, p. 98, \$186. Similar argumentation was used by Lord Bingham in Jones v. Saudi Arabia. Lord Bingham opined that "Ferrini decision cannot [...] be treated as an accurate statement of international law as generally understood; and one swallow does not make a rule of international law." Jones v. Saudi Arabia, $\$ 22$.

62 Al-Adsani, $\$ 66$.

63 FOX, H.: supra note 3, p. 582.

(c) Palacký University Olomouc, Czech Republic, 2011. ISSN 1213-8770 (print), ISSN: 2464-6601 (online). 
It was argued that state immunity concerns rules which are of procedural character, with the consequence that assessment of these rules follows the law in force at the time when a court is seized. The doctrine of inter-temporal law is not applied here and therefore state immunity can be interpreted in the light of current international law. Second, it was argued that well established exception, which provides for non-immunity once death, injury or damage is at least partly done on the territory of the forum state, is rather not applicable in relation to the armed forces. This conclusion is supported by the ECHR case-law (McElhinney), domestic case-law (Margellos) and work of the ILC. At the same time, some hesitation was revealed as to the interpretation of the UN Convention Art 12 - while state practice tends to exclude armed forces from its scope, there are arguments (modes of interpretation) which are indicative of their inclusion. Lastly, it was submitted that current international law of state immunity has not yet absorbed exception enabling to claim damages before domestic courts for serious human rights violation committed by foreign states. The most persuasive argument points to the lack of relevant state practice in this area. It was argued that as far as compensation for damages suffered during armed conflict is concerned, international humanitarian law does not accept right of individual to present claims on his/her own.

At the same time sympathy for Italian initiative was presented. Even the ECHR admitted that customary international of state immunity can develop in the future. Uniqueness of German-Italian dispute should be taken into account. Immunity Case contains three aspects which are of some difficulty and controversy - first one deals with inter-temporal law (events occurred during WW 2), second one concerns territorial facet (damage was at least partly caused on the territory of the forum state), last one aims to the author of wrongful act (atrocities were committed by the armed forces). If one imagines situation of violation of human rights which is current, isolated and not committed by the armed forces, despite it takes place outside the territory of the forum state (Al-Adsani scenario), much of the convincingness contained in German arguments simply disappears. It should be exactly this path which can lead to overall acceptance among states not to claim immunities where serious human right violations are at stake. It remains to be seen how long this path will be. 